\title{
The Preferences of Indonesian Outbound Tourists Toward Travel Types and Tourism Attributes
}

\author{
Farah Nur Azizah ${ }^{1}$, Devi Roza K.Kausar ${ }^{2}$, I Made Adhi Gunadi ${ }^{3}$, Yulan Yuan ${ }^{4}$ \\ 를ahnur59@gmail.com, ${ }^{2}$ devikausar@univpancasila.ac.id, ${ }^{3}$ made.gunadi@univpancasila.ac.id, \\ 4yoyoyuan@go.thu.edu.tw \\ ${ }^{1-2-3}$ Tourism Faculty Universitas Pancasila, Srengseng Sawah Jagakarsa, Jakarta, Indonesia \\ ${ }^{4}$ Dept of Landscape Architecture Tunghai University, Taiwan Blvd, Taichung City 407, Taiwan ROC
}

\begin{abstract}
Outbound tourists in Indonesia showing increasement every year, so it is very appealing to know the preference of Indonesian tourists in travelling abroad. This study investigates on the preferences of Indonesian tourist, following to the travel types and tourism attributes by Cohen and Mill. The purpose of this study is to develop an understanding of the types and evaluations of Indonesian outbound tourists. The survey conducted by using questionnaire to 200 Indonesian tourists. Factor analysis applied to reduce total of 11 travel types items and 23 tourism attributes items consisting of general conditions at the destination as well as accommodation and transportation, become a more basic factor. The result shows that the travel types of Indonesian outbound tourists fall into the category of organized mass-tourist. While the hospitality, facilities and transportation become an important tourism attributes. Travel types and tourism attributes also have a significant and positive correlation one another.
\end{abstract}

Keywords: travel types, tourism attributes, outbound tourist, organized mass-tourist

\section{Introduction}

In the modern era, tourism is currently experiencing a rapid growth and development. The existence of tourism activities encourages people to travel and doing a trip. Along with development of globalization and transportation technology, travel is become more convenient, easy, borderless and no longer limited by distance and time. According to UNWTO [1], tourism will become a great industry with an average international tourist growth of $7 \%$ which equal to 1.3 million each year. In Indonesia, tourism has become a trend and lifestyle, mostly supported by growing level of welfare among Indonesia's citizen. According to Cigna Corporation, welfare index of Indonesia is among the top five globally [2] .

In traveling, tourists have preferences to determine the best value in order to decide the tour destinations. From the attributes selection and determination of the value of tourism, each tourist will show their own characteristic. According to Cohen [3] tourist are classified based on familiarization of the destination and travel/trip organizing, which are drifter, explorer, individual mass-tourist and organized mass-tourist. Tourism is an experience which only be felt by own self and it is very complex to measure. In this case the use of attributes can help, where the attributes itself are the dimensions or elements that formed an assessment to evaluate the consumption experience even though the experience is narrow or abroad [4]. According to Mill [5] the tourism attributes consist of attractions, facilities, transportation, and hospitality. Research by Brau and Cao [6] discovered that the most valued thing by tourist is the population density, in order to have sufficient access to the main tour/travel attraction. Thus, it is shown 
that the supporting facilities such as recreational facilities or tourist attraction as well as destination access and location determinants that are close to other tours are the main determinants in attracting tourists.

Data shown by the Ministry of Tourism and BPS is showing steady and increase in national tourist growth. Data from Antavaya, one of prominent Indonesia travel agents, also showing that $85 \%$ of their Indonesia clientle is choose Europe and Asia as the most chosen destination countries. Hence, it's interesting to identified more detail about the travel type and the preferences of tourism attributes among Indonesian tourist in traveling abroad, and the relation of both variables. This research is also a part of joint research with Tunghai University Taiwan.

\section{Research Method}

This study uses a quantitative correlation research method, aim to find relations between variables and determine how closely the relationship is. The location of this research is mainly in the Jakarta area, considering that people who live in Jakarta are come from all over Indonesia and have a high level of mobility and prosperity. The field survey carried out using a questionnaire distributed to 200 respondens ranging in age from 12 years to over 66 years. To reach respondent living in different cities of Indonesia, both offline and online questionnaire with likert scale is used. The data obtained then processed using SPSS application for statistical analysis. This research uses two analysis:

a. Analysis of the respondent responses; this is to identify the highest and lowest data of travel type and tourism attributes.

b. Correlation analysis to find out the relationship between travel types with the tourism attributes.

After the data is obtained then analyzed with factor analysis to explain the relationship or correlation between variables to determine the right and appropriate preferences between types of travel with tourism attributes.

\section{Finding and Discussion}

From a total of 200 questionnaires distributed, the characteristics of respondents can be seen in table 1 . The totals of female respondents are $63 \%$ while male respondents are $37 \%$. Out of the seven age characteristics, the majority of the total respondents were young adults (50\%) with an age range of 20-29 years while the elderly ages $60-65$ years only $2 \%$. Meanwhile, for the number of visits, having one visit is constitutes the majority answers from respondents with a frequency of $38 \%$, and the lowest is four times with a frequency of $2.5 \%$. The motivation of Indonesian outbound tourists is for vacation $(82.5 \%)$ whilst the least motivation is carry out educational activities (11\%). The top five of visited countries by Indonesian outbound tourists Indonesia are Australia (7.5\%), Japan (26.5\%), Malaysia with a frequency of $9 \%$, the Netherlands with $7.5 \%$ and Singapore with a frequency of $19 \%$. So it was found that the majority of respondents were young adult women with age range of 20-29 years with having only onetime experience visiting abroad, with the motivation for holiday and the most visited countries were Japan. 
Table 1. Respondent Characteristic

\begin{tabular}{|c|c|c|c|}
\hline Description & Characteristic & $\mathbf{F}$ & $(\%)$ \\
\hline & Total Of Visit & & \\
\hline Never & & 0 & $0 \%$ \\
\hline One time & & 76 & $38 \%$ \\
\hline Two time & & 63 & $31.5 \%$ \\
\hline Three times & & 28 & $14 \%$ \\
\hline Four times & & 5 & $2.5 \%$ \\
\hline Five times & & 15 & $7.5 \%$ \\
\hline \multirow[t]{2}{*}{ More then five times } & & 13 & $6.5 \%$ \\
\hline & Travel Motivation & & \\
\hline Holiday & & 165 & $82.5 \%$ \\
\hline Visiting Friends \& Relatives & & 3 & $1.5 \%$ \\
\hline Business & & 1 & $0.5 \%$ \\
\hline Study & & 22 & $11 \%$ \\
\hline Medical Tourism & & 0 & $0 \%$ \\
\hline Conferences and Exhibitions & & 0 & $0 \%$ \\
\hline \multirow[t]{2}{*}{ Others } & & 9 & $4.5 \%$ \\
\hline & Destinations Countries & & \\
\hline Australia & & 15 & $7.5 \%$ \\
\hline Japan & & 53 & $26.5 \%$ \\
\hline Malaysia & & 18 & $9 \%$ \\
\hline Netherland & & 15 & $7.5 \%$ \\
\hline Singapore & & 38 & $19 \%$ \\
\hline Others & & 61 & $29 \%$ \\
\hline
\end{tabular}

\section{Descriptive Analysis}

Analysis conducted on the types of travel and tourism attributes, to find out which type of Indonesian tourists and attributes that support or are considered important for these types of Indonesian tourists. The results obtained for the types of Indonesian outbound tourist are as follows:

Table 3 Response of Travel Types

\begin{tabular}{lc}
\hline Statement & Indeks (\%) \\
\hline Use the travel package & $72.6 \%$ \\
Plan yourself then use a travel agent & $73.2 \%$ \\
Group trips organized by travel agent & $87.2 \%$ \\
Solo travel or backpacker & $82.7 \%$ \\
Use a travel guide & $80.2 \%$ \\
Travel with family and friends & $88.2 \%$ \\
Mingle with local life & $64.1 \%$ \\
Travel comfort & $90.1 \%$ \\
Avoid groups & $57.1 \%$ \\
Visit the place that is still original & $68 \%$ \\
Buy new items before price down & $69.5 \%$ \\
Source: The researcher $(2019)$ &
\end{tabular}

Seen from the statements of respondents that the types of Indonesian outbound tourist are detailed in three categories, which is comfort while traveling is very important, amounting to $90.1 \%$. Travel with family and friends, amounting to $88.2 \%$. And travel with groups organized by travel agents, amounting to $87.2 \%$. Those finding suggested that Indonesian outbound tourist are more related to the types organized masstourist. This type of tourist is prefer to only visit well-known tourist destinations, with facilities such as those that can be found in his origin country and his journey is always guided by a tour guide. 
The results obtained for the general conditions attributes of Indonesian outbound tourist are as follows:

Table 4 Response of General Condition Attributes

\begin{tabular}{lc}
\hline Statements & Indeks (\%) \\
\hline Health attention & $85.1 \%$ \\
Feeling secure & $88 \%$ \\
Cultural and linguistic diversity & $79.3 \%$ \\
Different sensation & $83.4 \%$ \\
Have relative or friends at their destinations & $72.7 \%$ \\
Cheap travel packages & $84.4 \%$ \\
Disability friendly & $75.8 \%$ \\
Many things for adults to see and do & $81.1 \%$ \\
Information is easly to found on internet & $84 \%$ \\
Desired goals & $82.7 \%$ \\
Ease of visa process & $89.8 \%$ \\
Family friendly & $90.4 \%$ \\
Mosleem visitor friendly & $78.3 \%$ \\
Direct flight & $81.6 \%$ \\
Local culture & $85.5 \%$ \\
Source: The Researcher (2019) &
\end{tabular}

Seen from the statement of the respondents that the top three of common attributes of general conditions are family friendly destinations $(90.4 \%)$, ease in visa process $(89.9 \%)$ and the feeling secure $(88 \%)$. The score showing the importance of these attributes according to Indonesian outbound tourists. These attributes are important because it fits to the travel type of Indonesian outbound tourists which is organized mass-tourist that look for comfort when traveling with family or group.

Whereas respondents statement who had the lowest score in is having friends or relatives at the destination (72.7\%), destination that is friendly to people with disabilities $(75.8 \%)$ and moslem visitor friendly $(78.3 \%)$. Those lowest score showing that these attributes in destinations considered unimportant by Indonesian outbound tourists. These attributes are considered not important because the available or unavailability of these attributes do not influence Indonesian outbound tourists in traveling abroad.

The results obtained for the accommodation and transportation attributes of Indonesian outbound tourist are as follows:

Table 5 Response of accommodation and Transportation Attributtes

\begin{tabular}{lc}
\hline Statement & Index (\%) \\
\hline Luxury accmmodation & $56.9 \%$ \\
Middle calssaccommodatios & $71 \%$ \\
Affordable accommodation & $49.3 \%$ \\
Homestay & $54.1 \%$ \\
Camping site & $49.3 \%$ \\
Comfort traveled by car & $61.1 \%$ \\
Ease of diret access by plane & $48.7 \%$ \\
Convenience of trains and buses & $51.4 \%$
\end{tabular}

Source: The researcher (2019)

Seen from the statement of respondents the attributes of accommodation and transportation are considered the most important in the three highest categories, that is the middle class accommodation (lodging) by $71 \%$. comfort traveled by car, amounting to $61.1 \%$. luxury accmmodation, amounting to $56.9 \%$. With the highest score it contributes to the attributes of accommodation and transportation at the destination chosen by Indonesian outbound tourists. These attributes are important because according to the type of travel 
(organized mass-tourist) outbound tourists need accommodation (accommodation) with a scale of four and five-star hotels and comfort when traveling using land vehicles at their destination.

Whereas with the statement of respondents who have the lowest value in three categories that is ease of direct access by plane, by $48.7 \%$, campng site by $49.3 \%$ and affordable accommodation, amounting to $49.8 \%$. With the lowest score making these attributes considered unimportant in general conditions in tourist destinations by Indonesian outbound tourists. These attributes are considered important according to tourists because the type of Indonesian outbound tourists does not matter direct and indirect or must transit during the flight because what is preferred by tourists is comfort.Affordable accommodation and camping spots are not important according to tourists because tourists need comfort and adequately services for accommodation.

In the general condition attribute, the most chosen attribute by the respondent is "family friendly " included in the Hospitality attribute. In the conditions of accommodation and transportation attributes, the most frequently chosen by respondents is " middle class accommodation" which is included in the attributes of facilities and "Comfort traveled by car" included in the transportation attribute. These attributes are in accordance with the theory put forward by Mill [5].

\section{Correlation Analysis}

Travel Type and General Condition Attributes

Based on the results of the correlation coefficient it can be understood that between the type of trip and the general condition attributes have a relationship that is directly proportional and the correlation is positive. This means that when an increasing type of travel (organized mass-tourist) travels abroad, it will be accompanied by a higher level of the general condition attributes to the assessment of Indonesian outbound tourists in traveling abroad. In accordance with the type of Indonesian outbound tourists, namely the type of organized mass-tourist trip, this type is the type of tourist who wants general conditions at the destination with high or very adequate conditions.

Travel Type with Accommodation and Transportation Attributes

Based on the results of the correlation coefficient it can be understood that between the type of travel with the attributes of accommodation and transportation have a relationship that is directly proportional and the correlation is positive. This means that when the type of travel (organized mass-tourist) to travel abroad increases, it will be accompanied by the higher attributes of accommodation and transportation into the assessment of Indonesian outbound tourists in traveling abroad. This type is the type of tourist who wants adequate accommodation conditions at their destination. This can also be seen from the results of the data obtained that the attributes of accommodation and transportation that have important values according to organized mass-tourist tourists.

\section{Conclusion and Recommendation}

In the results of research on the type of trip consisting of drifters, explorer, individual masstourist and organized mass-tourist, the results obtained that the highest type obtained is the type of organized mass-tourist. In the results of research on the attributes of tourism which consists of attractions, facilities, transportation and hospitality as outlined in the attributes of general conditions and attributes of accommodation and transportation. So that tourism attributes that are considered important by respondents can support Indonesian outbound tourist type travel activities.

Based on the results and discussion of the research, there is a proportional relationship and positive correlation between the type of travel with the attributes of the general conditions and the 
attributes of the accommodation of transportation. The type of Indonesian outbound tourist travel is organized mass-tourist which has a significant relationship in the preferences of tourism attributes, namely the friendly for families, the ease of visas process, and having middle class accommodations and luxury class accommodation.

Based on the conclusions obtained from the research, some suggestions can be made as follows: Travel agencies have enormous chance and opportunities to develop tour packages for Indonesian outbound tourists in accordance with the criteria packages for organized mass-tourist types; Destination managers in destination countries should provide and take more attention to tourism attributes that are being considered important by Indonesian outbound tourists, especially in the area of hospitality, facilities and transportation; and Travel agencies and destination managers still need to provide good alternatives for travel packages and tourism attributes, to deal with the changing profile and dynamic trends of tourists.

\section{References}

[1] www.unwto.org accessed on 22 July 2019.

[2] Nurmayanti. Tingkat Kesejahteraan Masyarakat RI Masuk 5 Besar indeks Global. on liputan6.com (2019), accessed on 7 August 2019

[3] Cohen E. Who is a Tourist? A Conceptual Clarification. Sociological Review (1972)

[4] Smith R \&Deppa B. Two dimension of attribute importances. Journal of Consumer Marketing Vol 26 (1) page 28-38. (2009)

[5] Mill R C. Tourism: The International Business. New Jersey: Patience Hall (2010)

[6] Brau R dan Cao D. Uncovering the Macrostructure of Tourists' Preferences. A Choice Experiment Analysis of Tourism Demand to Sardinia. Thesis. Italy: Dipartimento di Economia and CRENoS, Università di Cagliari. (2006) 